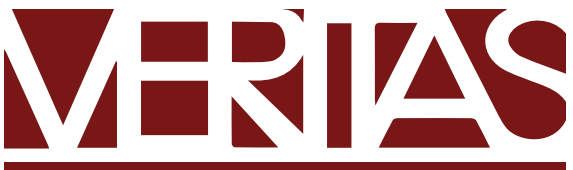

$\begin{array}{lllllllllll}P & O & R & T & O & A & L & E & G & R & E\end{array}$

\title{
A SENTENÇA DE PROTÁGORAS SOBRE OS DEUSES E A UNIDADE DE SUA DOUTRINA
}

\author{
Protagoras' statement on the gods and \\ the unity of his doctrine \\ La sentencia de Protágoras sobre los dioses y \\ la unidad de su doctrina
}

M. R. Engler ${ }^{1}$

Universidade Federal do Paraná, Curitiba, PR, Brasil.

\section{Resumo}

Discuto neste artigo o fragmento de Protágoras sobre a existência dos deuses e a sua coerência teórica com outras teses do sofista. Primeiramente, utilizo dados históricos e biográficos para iluminar o subjetivismo da primeira linha do fragmento (introdução ). Em seguida, discuto os obstáculos epistemológicos mencionados por Protágoras e sugiro uma nova tradução para o termo brachýs, um dos conceitos centrais que ele propõe (seção 1). Na seção 2, analiso o ataque à transcendência que distingue suas ideias sobre a matemática e a percepção sensível. Finalmente, na seção 3, mostro como a sua postura teológica está de acordo com a tese do homo-mensura e com a sua

1 Doutor em Filosofia (UFSC). Professor do Departamento de Teoria e Fundamentos da Educação (DTFE) e do Programa de Pós-Graduação em Filosofia da Universidade Federal do Paraná (UFPR). https://orcid.org/o000-0001-6752-259X. E-mail: reusengler@gmail.com 
abordagem antilógica. A conclusão ressalta a unidade do pensamento de Protágoras e a sua posição no lluminismo grego.

Palavras-chave: Protágoras. Deuses. Subjetivismo. Brachýs. Ataque à transcendência.

\begin{abstract}
In this article, I discuss Protagoras' fragment on the existence of gods and its theoretical coherence with his other theses. Firstly, I use historical and biographical factors to illuminate the subjectivism of the fragment's first line (introduction). I then discuss the epistemological obstacles mentioned by Protagoras and suggest a new translation for the term brachýs, one of the chief concepts he proposes (section I). In section II, I analyze the attack on transcendence that distinguishes his reflections both on mathematics and on sense perception. Finally, in section III, I show how his theological posture is in accordance with his homo-mensura thesis as well as his antilogical approach. The conclusion emphasizes the unity of Protagoras' thinking and his position within the Greek Enlightenment.
\end{abstract}

Keywords: Protagoras. Gods. Subjectivism. Brachýs. Attack on transcendence.

\title{
Resumen
}

En este artículo proponemos discutir el fragmento de Protágoras sobre la existencia de los dioses y su coherencia teórica con otras tesis del sofista. En primer lugar, utilizo datos históricos y biográficos para iluminar el subjetivismo de la primera línea del fragmento (introdución 1). Luego, discuto los obstáculos epistemológicos mencionados por Protágoras y sugiero nueva traducción para el término brachýs, uno de los conceptos centrales que propone (sección I). En la sección II, analizo el ataque a la trascendencia que distingue sobre matemáticas y la percepción sensible. Por último, en la sección III muestro cómo su potura teológica está de acuerdo con la tesis del homo-mensura y con su enfoque antilógico. La conclusión señala la unidad del pensamiento de Protágoras y su posición en el lluminismo griego.

Palabras clave: Protágoras. Dioses. Subjetivismo. Brachýs. Ataque a la trascendencia. 
"Poîos Zeús; ou mè̀ lērếseis: oud' esti Zeús". (Aristófanes, Nub. 367)2.

\section{Introdução: religião, lluminismo e impiedade}

\section{Conquanto o embate entre ciência e religião seja amiúde visto como} um fenômeno estritamente moderno, fortes razões há para crer que, em virtude da contraposição entre razão e crença, ele já tenha sido iniciado na Grécia antiga, máxime quando o programa de pesquisa da ciência jônica foi expandido para outras áreas e, no turbulento Século de Péricles, defrontou-se com o universo politeísta ${ }^{3}$. Esse momento desempenha papel de suma relevância dentro do que os filólogos costumavam chamar de lluminismo grego ${ }^{4}$ e representa, pois, um dos efeitos mais inequívocos do

\footnotetext{
2 "Que Zeus? Não digas bobagens! Não existe nenhum Zeus!" (tradução nossa).

3 Na visão de Lesky: "The basic assumptions of the sophistic movement had their origin in Ionia. At the price of some simplification and over-emphasis we might say that it represents the victory of Ionian curiosity over Attic conservatism (LESKY, 1963, p. 342) Jaeger (2011, p. 348 ) e Untersteiner (2012, p. 105) possuem praticamente a mesma opinião.
}

4 O termo "iluminismo grego" é corrente entre os helenistas desde o tempo de Hegel, como discutido abaixo. Para ele, o nível de cultura/formação (Bildung) alcançado pelos sofistas, no que toca à forma e ao conteúdo, era o mesmo do século XVIII; em ambos os casos o punctum saliens era a substituição da crença pela investigação racional. Cf. HEGEL, 1971. O paralelo foi aceito e desenvolvido por Eduard Zeller, a maior autoridade alemã do século XIX, em sua "monumentale histoire de la philosophie (1re éd., 1844-1852)" (BRISSON, 1991, p. 90-91), e assim criou-se uma narrativa bastante coerente sobre o papel desses pensadores na história da filosofia grega, narrativa essa que ainda hoje se mostra verdadeira. A despeito de criticar seu excesso de subjetivismo, depois retificado por Platão e Aristóteles, Zeller julga que os sofistas são os mais destacados porta-vozes do iluminismo do século $V$ e evidenciam todas as vantagens e fraquezas dessa posição, cumprindo assim um papel necessário na evolução do espírito grego (ZELLER, 1893, p. 77-78). Com algumas modificações, outros eminentes filólogos adotam tal paralelo e defendem que os sofistas anteciparam pontos fulcrais do iluminismo do século XVII, como o ataque à tradição, a crítica à religião, o valor da racionalidade, a tentativa de fundamentação racional da moral etc. "Since Hegel it has been usual to compare the sophistic movement with the 'enlightenment' of the eighteenth century, and there are many similar features which justify the comparison" (LESKY, 1963, p. 340-341). Além de Lesky, Walter Kranz, Ulrich Willamowitz, Theodor Gomperz, W. K. C. Guthrie, Werner Jaeger, Giovanni Reale e H. G. Gadamer, entre outros, subscreveram a analogia. Walter Kranz, v.g., fala de uma surpreendente similaridade (überraschende Ähnlichkeit) da estrutura espiritual dos dois períodos da história do pensamento, que se exemplifica na erupção da crítica e no apelo ao senso comum (KRANZ, 1981, 104). Giovanni Reale (2005, p. 197), por sua vez, acredita que o epíteto de iluministas define bem os sofistas, se se leva em conta "essa libertação espiritual de todas as tradições" que os caracte- 
movimento sofístico. Com um impacto embriagador sobre a cosmovisão de uma geração inteira, a nova educação (kainè paideía) 5 propugnada pelos sofistas não podia deixar incólumes as crenças religiosas. Sua inflexível aplicação da razão à phýsis e ao mundo dos deuses tradicionais agiu sobre a sociedade grega com um transe ${ }^{6}$ e contribuiu para criar o clima de ocaso que se intensifica nos anos da peste e atinge o apogeu no fim da Guerra do Peloponeso7 ${ }^{7}$ No seio desse vertiginoso processo de criação de ideias, as mais proeminentes figuras do movimento esboçam posturas caracteristicamente modernas sobre a existência do divino. Não obstante paire entre os estudiosos tal ou qual consenso sobre essas posturas, a sua

rizou. Atualmente, todavia, essa identificação tem sido criticada por vozes isoladas. Traureck (2005, p. 38) argumenta que, no que toca à critica religiosa, por exemplo, a diferença entre o politeísmo grego e o monoteísmo cristão, com suas instituições e dogmas, tornaria o paralelo inexato; o mesmo valeria para o campo da ciência, da política e da metafísica. Ao fim, as diferenças de contexto histórico e do próprio horizonte programático de ambos os movimentos invalidariam a comparação (TRAURECK, 2005, p. 41-42). Naturalmente, é impossível discutir aqui todos os detalhes dessa questão. No entanto, mantenho a posição de que houve, sim, um iluminismo grego, assente na ideia de secularização da natureza, que encontra nos sofistas seu auge e sua significativa expansão para temas humanos e sociais. Por isso, aliás, considero o termo humanismo sofístico, preferido por outros autores que se baseiam em Cícero, igualmente correto, uma vez que o humanismo da Renascença também retoma aspectos do pensamento dos sofistas. Porém, o conceito de iluminismo ainda me parece mais abrangente e apropriado, máxime por seu caráter crítico e secular.

5 A expressão é de Aristófanes, que põe em oposição a nova (sofística) e a velha educação. (Nub. 962).

6 A expressão é de Karl Joël, que denomina o movimento de "embriaguez da juventude (Rausch der Jugend) (JOËL, 1921, p. 674, apud Guhtrie, 1991, p. 50). Pensando no impacto dos sofistas, Lesky (1963, p. 357) também enfatiza o motivo do frenesi e usa a expressão Sturm und Drang para nomeá-los. Por sua vez, Gomperz (1952, p. 463) escreve: "La aparición de uno de estos corifeos era un acontecimento quentre producía viva inquietud en vastos círculos de la juventud ateniense". No começo do Protágoras pode-se ver, na figura de Hipócrates, o entusiasmo que um sofista causava (Prot. 310b).

7 Sobre as modificações culturais e sociais provocadas pelos sofistas: "But what they broke up was never put together again in Greek Life [...]" (LESKY, 1963, p. 341). "Damals wankte der Boden unter den Füssen" (Kranz, 1981, p. 98). A melhor descrição dos efeitos sociais da peste ainda se encontra em Tucídides (Thuc. II, 53), que ressalta a anarquia, o hedonismo e desespero que tomou conta dos atenienses. Também Plutarco retrata como os ânimos se alteraram em razão do sofrimento causado pela doença; ele liga esse fato às perseguições político-religiosas discutidas abaixo. Ora, a embaixada de Górgias a Atenas ocorreu por volta de 427 a. C, dois anos depois da peste, e Protágoras também esteve lá nesta época, já que louvou a atitude de Péricles ante a morte de seus filhos, levados pela epidemia. Ergo, é de supor que parte dessa animadversão se voltou contra os sofistas. Per. 32. Sobre isso, confira-se o estudo clássico de Dodds (1960, p. 179). 
caracterização permanece algo inexata e recorre muitas vezes a rótulos genéricos, sem o detalhamento conceitual adequado.

Nas páginas que se seguem, interpreto com maior precisão a posição de Protágoras, com o fito de mostrar que, no tocante a dois problemas teológicos centrais, a existência e o aspecto dos deuses, a sua perspectiva é marcada por um "agnosticismo antilógico" coerentemente derivado do âmago de sua doutrina. Além do subjetivismo ressaltado por Hegel, Zeller e Jaeger, defendo que a postura epistêmica de Protágoras se caracteriza mais propriamente pelo reconhecimento da pequenez das forças cognitivas do homem e de sua consequente incapacidade de extravasar o plano imanente das sensações e da matéria (seção 2). Em parte, essa conclusão é alcançada mediante a modificação da tradução vezeira do fragmento sobre os deuses, tradução essa que favoreceu o sentido quantitativo ("curto, breve") do termo brachýs em detrimento do sentido qualitativo ("humilde, ínfimo"). A meu ver, o sofista não visa a "brevidade”, senão a "pequenez" da vida humana. A partir disso, discuto o ataque à transcendência que distingue as demais reflexões de Protágoras sobre a natureza da alma, da matéria e da matemática. Nesses casos, ele rejeita toda a noção de transcendência e de suprassensibilidade (seção 3). Essa discussão ilumina, na sequência, duas famosas ideias do sofista: a tese do homo-mensura e da antilogia. Argumento, então, que a proclamação do homem como medida das coisas, em que pese seu aparente triunfalismo, deve ser compreendida como a constatação de uma restrição epistemológica, ou seja, como a admissão de que o homem está confinado a uma esfera de pura imanência e, em sua busca pela verdade, é incapaz de ultrapassar a própria medida. Isso se conecta com a abordagem antilógica, porque nesse âmbito nem sequer os discursos podem recorrer a um critério externo que garanta a sua veracidade, uma vez que se contradigam sobre todos os temas possíveis. Proponho igualmente que, ao adotar tais perspectivas, Protágoras alia-se a uma longa tradição grega que transforma a diferença entre deuses e humanos, outrora tematizada na tradição épica, em uma crítica paulatina de nossa capacidade de conhecer (seção 4). 
No fim, depois de detalhar conceitualmente o agnosticismo de Protágoras, a imagem que dele emerge é algo que diversa do retrato de orgulhoso sofista com que a tradição está acostumada. Ao contrário, ele aparece primeiramente como um pensador que, na esteira de certas tendências da filosofia pré-socrática e da cultura grega como um todo, é sobremodo atento à pequenez do homem e a sua humilde capacidade de medir-se com o Todo, ao mesmo tempo em que, no solo da crítica teológica, desponta como um pensador profundo e original, que acomoda harmoniosamente a sua visão sobre os deuses ao restante de sua doutrina.

\section{A sentença sobre os deuses: impiedade e subjetivismo}

No que diz respeito à religião, o caso de Protágoras é exemplar e pode ser que esteja na base de muitas reflexões e reprimendas que serão dirigidas a outros autores antigos que duvidavam da existência dos deuses ou reconheciam a dificuldade dessa questão ${ }^{8}$. Suas circunstâncias biográficas lançam alguma luz sobre esse fato. Ele pertenceu ao círculo vanguardista de Péricles e esteve em contato com Demócrito, Anaxágoras, Alcibíades, Hípias, Pródico, Cálias, Eurípides etc. Como um conselheiro político, a posição que os sofistas tomaram aos poetas, ele ganhou a confiança do primeiro homem da democracia ateniense, que o incumbiu de escrever a constituição da recém-fundada colônia de Túrio (443) (A1-DK), constituição essa que parece ter seguido a índole democrática de Atenas ${ }^{9}$. Outro fragmento relata que ele teria discutido

\footnotetext{
8 Ao catálogo de ateus pertencem Protágoras, Críticas, Pródico, Teodoro de Cirene, Diágoras e Evêmero. Eurípides, Demócrito e Epicuro são por vezes incluídos, segundo o hábito antigo de aumentar ou diminuir os catálogos. A lista aparece em Filodemo, Cícero, Sexto Empírico, Diógenes de Enoanada etc. Sobre isso: Gigon (1985, p. 423); Müller (1976, p. 328, n. 56; p. 329, n. 59).

9 Untersteiner (2012, p. 31) afirma que o mito do Protágoras não implica necessariamente um apreço pela democracia e que a constituição de Túrio deve ter tido cariz pan-helênico, limitando-se ao direito corrente no sul da Itália. Recordando que Esparta negou-se a participar da fundação dessa colônia, ficando isso a cargo de Atenas e cidades aliadas, Dherbey (1986, p. 215) argumenta que "não podia ser senão uma constituição de tipo democrático", o que parece mais acertado. Gigon (1985, p. 424-425) informa que, entre os responsáveis pela colonização de
} 
com Péricles, durante um dia inteiro, o problema da culpabilidade jurídica (A10-DK), e que teria louvado a firmeza de ânimo de que o estratego deu mostras quando a peste the ceifou os filhos (B9-DK). Ambos os relatos sugerem a que ponto chegou sua intimidade com o poderoso político. Não é precipitado supor, destarte, que Protágoras tenha defendido valores democráticos. Dherbey (1986, p.15) sustenta, por exemplo, que a tese da antilogia pode ser extraída do reconhecimento da pluralidade de opiniões, que constitui o punctum pruriens da democracia; e a partir do mito de Prometeu, relatado no Protágoras de Platão ${ }^{10}$, também é possível derivar

Túrio, havia apenas um espartano, sendo os demais atenienses; assim, ele não vê razões para a inclusão de Protágoras e critica a tradição dessa notícia, argumentando que poderia tratar-se de um equívoco baseado em outro fragmento de Heráclides Pôntico, que faz de Protágoras uma personagem de seu diálogo Sobre as leis. Para Jaeger (2001, p. 274-275), a ideia de que o Estado é um órgão educador, que aparece na oração fúnebre de Péricles, deve-se à influência dos sofistas. Isso favorece a ideia de uma possível atitude democrática de Protágoras e, a fortiori, de sua participação na fundação de Túrio.

10 Não me parece que o mito retrate fielmente a visão de Protágoras, e penso ser sensato que Diels-Kranz o tenham colocado entre os fragmentos C, isto é, as imitações. Untersteiner, Dherbey, Dupréel e Kerferd o tomam por majoritariamente protagórico, ao passo que Gigon (1985, p. 448) o considera uma brincadeira senza impegno de Platão, admitindo em seguida, todavia, que não se pode excluir completamente a ideia de que relate a doutrina do sofista. Müller (1976, p. 312) escreve que as posições extremas - dizer que é só de Protágoras ou só de Platão - não satisfazem ninguém. Penso que a bem-sucedida união entre mito e logos faz jus às virtudes epidíticas do sofista e é um traço da sofística, como se depreende do Hercules in Bivio de Pródico, assim como o uso da história especulativa de Hesíodo e sua descrição de uma situação humana desamparada devem recordar o escrito protagórico "Sobre a condição originária" (Perì tês en archê katastáseōs). Outras teorias sofísticas sobre a religião, especialmente a de Crítias (B25-DK) e a de Pródico (B5-DK), também recorrem à descrição de um estado originário da humanidade. Para Jaeger (1976, p. 65), essa era a tendência da "sociologia da religião" da época. O mito possui, portanto, alguns elementos inegavelmente protagóricos. Contudo, se ele for mesmo de Protágoras, então é preciso vê-lo como um escrito circunstancial, isto é, como parte de um argumento ad captandam benevolentiam em que o sofista, diante de um público ao qual deve parecer virtuoso, fala da irmandade (dià tèn tou theoû syngéneian) do homem com os deuses (Prot. 322a) - algo que viola claramente seu agnosticismo - a fim de não soar demasiado ímpio. Noutras palavras, no mito o sofista possui um conhecimento sobre os deuses que contraria seu fragmento B4, razão pela qual é preciso perguntar se espelha a doutrina de Protágoras ou se é, ao contrário, uma opinião suscitada pela ocasião. Dado que Platão sabia da posição de Protágoras sobre os deuses (Tht. 162d), essa pergunta faz ainda maior sentido. Por esse motivo, Guthrie (1995, p. 65) afirma que a introdução dos deuses não deve ser levada a sério, sendo apenas um adorno ao mito. Estudiosos de Platão como Friedländer e Cherniss negam a origem protagórica do mito com base na questão da irmandade com os deuses (Cf. MÜLLER, 1976, p. 314). A meu ver, mais do que a irmandade, o que o torna suspeito é a menção do dom divino (theîa moîra), um conceito que Platão desenvolve precisamente para criticar a posição dos sofistas. Cf. ENGLER, 2016, cap. III. Já se aventou na Antiguidade uma interpretação 
certo apreço pela democracia, haja vista as virtudes civis ali elencadas, a reverência/respeito (aidốs) e o senso de justiça (díkē), sejam distribuídas indistintamente aos seres humanos (Prot. 322d1-3). Porquanto acusações de impiedade e ateísmo fossem frequentemente usadas na época para atacar figuras demasiado sobressalentes, como o julgamento de Sócrates revela, a perseguição de cunho religioso sofrida por Protágoras deve ser em parte atribuída ao cenário político. Afora o conhecido caso de Anaxágoras, Aspásia e Fídias, a amante e o principal artista protegido por Péricles, também padeceram processos judiciais cujo real intento era diminuir o poder do estratego: este supostamente por roubar o ouro destinado às obras do Partenão", aquela por cometer impiedade (asébeia) e receber prostitutas para gozo de Péricles (Per. 31; 32).

No contexto da discussão da influência de Péricles e de suas relações, Plutarco relata a promulgação de um decreto público ( $p$ séphisma) expedido pouco antes da Guerra do Peloponeso por incitação de certo Diopites - personagem algo obscura, que aparece em Aristófanes e demais comediantes como adivinho, fanático religioso e tocador de tambor nos ritos coribânticos

que, em relação ao fragmento sobre os deuses, identifica uma estratégia retórica por parte de Protágoras. Diógenes de Enoanda afirmou que Protágoras tinha a mesma opinião que Diágoras de Melos, a saber, que era ateu; porém, para evitar o excessivo atrevimento (tò lian itamón) dessa postura, socorria-se de expressões atenuantes, como em seu fragmento sobre o agnosticismo (A23-DK). Esta ideia abre a possibilidade de que, como uma estratégia a Leo Strauss, Protágoras tivesse ensinamento esotérico similar àquele que Plutarco atribui a Anaxágoras. Hemmenway (1996) desenvolve cabalmente essa leitura, tentando expor o que o sofista pensava de verdade, e não o que oculta literariamente em seu mito. Para ele, desde o início Sócrates alerta para o perigo de entregar-se ao sofista, e Protágoras, ao decidir conversar, pergunta ao filósofo se este prefere fazê-lo em público ou em privado, o que sugere uma diferença entre o conteúdo do que irá dizer. Há uma luta então para que o sofista revele seu pensamento (HEMMENWAY,1996, p. 21): Sócrates se esforça para que Protágoras deixe de esconder seu hedonismo e sua visão instrumental do conhecimento. Embora não possa avaliar aqui a tese de Hemmenway como devido, sua leitura parece correta em muitos pontos. Assim, os elementos mais protagóricos do mito são: a) a descrição desamparada da condição humana, que faz eco a Hesíodo e que concorda com os demais fragmentos; b) a crença na técnica/ciência como forma de superar o rude domínio da natureza, tendência geral do humanismo sofístico; e c) e a visão instrumental da religião que transparece na ideia de que o homem é o único ser que crê nos deuses e que se assemelha, outrossim, à visão de Pródico e de Critias, como assinalado por Jaeger.

$"$ O processo de Fídias pode ter sido um caso de profanação de templo ou imagem sagrada (hierosylía), pois ele teria roubado o ouro destinado a uma estátua votiva. Isso torna sua ligação com os outros casos ainda mais cerrada. Cf. MÜLLER, 1976, p. 355. 
(GUTHRIE, 1995, p. 213) - que condenava a impiedade (asébeia) daqueles que menoscabavam o divino (tà theîa mè nomízontas) ${ }^{12}$ ou professavam doutrinas inovadoras sobre os astros (perì tōn metarsíon lógous didáskontas) (Per. 32.1). De acordo com Plutarco, que provavelmente se refere ao fato de o filósofo de Clazômenas desconsiderar a divindade do sol, ao afirmar que ele era uma massa incandescente maior que o Peloponeso (A1-DK), a acusação estendia-se a Péricles através de Anaxágoras. Como sabido, Péricles arquitetou a fuga de seu mestre. Em Plutarco, o próprio Péricles aparece desdenhando um eclipse e explicando-o como um fenômeno natural. A anedota relata o seguinte: em virtude de um eclipse, o medroso timoneiro do barco de Péricles recusava-se a navegar. Péricles teria, então, usado seu manto para tapar os olhos do timoneiro e, depois de mostrar-lhe que nada de mal havia ocorrido, ter-lhe-ia explicado que o eclipse era tão-somente um manto em escala maior, razão pela qual ele devia deixar de lado seu medo, içar as velas e partir (Per. 35.2) Tanto o título da comédia de Aristófanes que ataca filósofos e sofistas, Nuvens, como as esdrúxulas doutrinas que nela desfilam, pois, exemplificam à perfeição como os estudos astronômicos foram desde cedo associados à impiedade e, portanto, tornaram-se objeto de crítica por parte de conservadores religiosos ${ }^{13}$.

Embora os dados acerca de Diopites sejam relativamente obscuros, várias fontes mencionam a perseguição sofrida por Protágoras, e

\footnotetext{
12 Esta expressão, ora utilizada com o verbo eînai, designa tanto a descrença nos deuses quanto a atitude de desdém em relação a eles. Para a discussão de seu significado, bem como para as passagens em que aparece. Cf. TATE, 1936, p. 3-5; 1937, p. 3-7.

13 Na vida de Nícias, Plutarco relata que Anaxágoras foi o primeiro a escrever as doutrinas mais ousadas sobre as fases da lua, e que elas circulavam secretamente entre poucas pessoas. Ele pertencia, assim, aos físicos e "tagarelas" (meteōroléschas) que reduziam o divino a causas irracionais. Logo depois, Plutarco menciona o exílio de Protágoras e a morte de Sócrates, o qual nada tinha que ver com tais doutrinas. Nic. 23, 2-3. Isso exemplifica a ligação da astronomia com a impiedade. Embora Protágoras não seja normalmente visto como um "físico", uma comédia de Éupolis, Aduladores (circa 421), o acusa de ser um "físico criminoso (alitếrios) que se jacta (alazoneúetai) sobre as coisas do céu enquanto desdenha as da Terra" (A11-DK). Segundo Gigon (1985, p. 421), a comédia tratou frequentemente de Protágoras. Essa contraposição entre olhar para o céu e esquecer-se dos bens terrenos, parece-me, ecoa no Teeteto de Platão, especificamente na história de Tales (Tht. 174a); isto é, Platão deve ter evocado ao mesmo tempo a opinião corrente sobre a astronomia e os aspectos cômicos da situação.
} 
Diógenes Laércio a relaciona a uma acusação específica feita por um dos Quatrocentos Tiranos, Pitodoro'14. A data da acusação é debatida entre os estudiosos, já que alguns consideram que Protágoras teria morrido pela década de vinte, ao passo que outros estendem sua vida até a tirania dos Quatrocentos (411), quando teria acontecido o processo. Trata-se de um pormenor irrelevante para os presentes propósitos. O que importa salientar é que, em razão dessa acusação, promulgou-se um decreto público (eisangelía) que ordenava, por meio de um arauto, seus livros fossem reunidos e depois queimados em praça pública, o que de fato veio a acontecer (A4-DK). Em uma das versões de sua morte, para evitar ser obrigado a beber aquilo que Tímon chama de "a gélida bebida de Sócrates" (A12-DK), Protágoras abandona Atenas em direção à Sicília e, na tentativa de desviar das naus atenienses que patrulhavam o mar, acaba falecendo com o naufrágio de sua humilde embarcação. O mais importante aqui é que a grande maioria das fontes concorda em que foi justamente a sentença sobre os deuses - Diógenes Laércio (dià taútēn tè̀n archè̀n toû syngrámmatos A1-DK); Filóstrato (dià mèn dè toúto A2- DK); Hesíquio (eîpe gàr A3-DK); Cícero (cum in principio libri sic possuisset A23-DK) e Sexto Empírico (par'èn aitían thánaton autoû A12-DK) - a qual pode ter composto a abertura de seu livro intitulado Antilogias ${ }^{15}$, que ocasionou tal perseguição ${ }^{16}$. Para piorar, Protágoras teria feito a leitura pública do

\footnotetext{
14 Lesky comenta: "At all events, it was there [sc. in Athens] that he was threatened by Pitodorus with an action of impiety, which he escaped by timely flight. His books were publicy burnt, and he himself is said to have lost his life while sailing to Sicily: a fact which seems to be unkown to Plato (Men. 91e). Pitodorus represents the reaction of Athenian conservatives to the sophists. He belonged to the oligarchical circles which planed the putsch of 411 , and it was about this time that the attack on Protagoras was made" (LESKY, 1963, p. 342-343).

15 Diógenes Laércio afirma que a sentença sobre os deuses pertenceria a um livro autônomo de mesmo título (A1-DK). Untersteiner (2012, p. 37) reorganiza os títulos conservados por Diógenes, porém, e compreende o escrito como uma seção de abertura do livro Antilogias. Gigon (1985, p. 435) é de opinião de que se tratasse de livro autônomo. A resolução dessa questão não possui interesse imediato para os presentes propósitos. Müller (1976, p. 319) julga que se trata de questão de somenos relevância.

16 Autores modernos tentaram desmentir a história sobre o processo sofrido por Protágoras alegando que Platão, no Mênon, afirma que o sofista morreu tranquilamente e com enorme fama (A8-DK). Gigon (1985, p. 432) pensa que Platão não teria feito tal afirmação, tivesse o
} 
livro em casa de Eurípides, outro nome desde sempre tingido pela pecha de ateísmo ${ }^{17}$. Em resumo, à parte o que se pode derivar de sua ligação com Péricles e demais intelectuais progressistas, bem como da atmosfera de histeria contra a impiedade que se alastrou na esteira da peste e da Guerra do Peloponeso ${ }^{18}$, foi justamente por sua posição sobre os deuses que Protágoras foi obrigado a exilar-se de Atenas.

Em sua forma mais completa, a sentença afirma:

\begin{abstract}
Sobre os deuses não tenho como saber (ouk échō eidénai) nem se existem (hós eisìn), nem se não existem e qual seria seu aspecto (idéan); muitas coisas, pois, impedem (tà kōlýonta) tal saber, como a obscuridade (adēlótēs) [da questão] e
\end{abstract}

sofista morrido do modo dramático como relatado no fragmento. A história do processo e especialmente do naufrágio seria uma tentativa de fontes antigas de mostrar o destino que os deuses reservam para os ateus. Por isso ela viria relacionada, no testemunho de Filócoros, ao Íxion de Eurípides, personagem que, como Protágoras, padece atroz destino por ser inimigo dos deuses (theómachos) (Idem, 1985, p. 431). Filóstrato relata, com efeito, que alguns acreditavam que Protágoras teria sido julgado, ao passo que outros eram de opinião que não teria sido julgado, mas apenas punido pelo decreto (A2- DK). Isso prova que a história era controversa já na Antiguidade. No entanto, as demais fontes a tomam por verídica e o próprio Protágoras platônico, como recorda Kerferd (2003, p. 39-40), diz que sua profissão envolvia enorme risco e despertava grandes ódios (Prot. 316c5-e5). A hesitação de Gigon pode provir de um fato externo: a dificuldade que os eruditos do século XIX tinham em admitir que a ilustrada Atenas foi palco de supersticiosas perseguições. Para Dodds, que escreve depois da 2. ${ }^{a}$ Guerra Mundial, isso é algo compreensível (DODDS, 1960, p. 179). Müller (1976, p. 331; 337) discute todos os testemunhos e conclui que uma resposta final é impossível.

17 Não há certeza sobre essa informação acerca do local de leitura. Porém, as ligações entre Eurípides e Protágoras deixam-se ver, por exemplo, em uma provável imitação (C4-DK) ou alusão nas Bacantes (199ss), onde o dramaturgo afirma que não irá desdenhar (kataphronō) dos deuses e que nenhum discurso há de demolir (katabaleî) a crença neles. As duas ideias se ligam a Protágoras, especialmente a última, que recorda o subtítulo de um de seus livros, Katabállontes lógoi. De modo geral, a obra de Eurípides reflete as indagações filosóficas da época e já espelha as dúvidas sobre os deuses a que muitos sábios haviam chegado. Belerofonte, personagem de um fragmento conservado, afirma que a existência dos deuses mais não é do que uma desusada estupidez (Frag. 286). Tal como Íxion e Sísifo, outros protagonistas de Eurípides, Belerofonte é um theómachos, um inimigo dos deuses (KERFERD, 2003, p. 288). Nas Rãs (888-894), Aristófanes também atribui a Eurípides a crença no Éter, divindade da religião naturalista da época. Por tais motivos, reconhece-se que Eurípides absorveu intensamente os ensinamentos dos sofistas.

18 Comentando a reação ao lluminismo grego, encabeçada pelos processos de impiedade mencionados, Dodds afirma (1960, p. 180): "Más importante, quizá, fue la influencia de la histeria del tiempo de guerra. Si tenemos en cuenta que el hecho de que las guerras van precedidas de sombras y seguidas de disturbios emocionales, la Epoca de la Persecución coincide bastante exatamente com la guerra más larga y más desastrosa de la historia griega". 
o fato de ser a vida (bíos toû anthốpou) humana pequena/ ínfima (brachýs) (B4-DK, tradução nossa).

O primeiro ponto a ser frisado sobre a sentença está no subjetivismo que professa. A linha inicial deixa claro que a impossibilidade de um saber concreto sobre os deuses ocorre ao sujeito do enunciado: não the é possível saber (ouk échō eidénai) qual das duas hipóteses é verdadei$\mathrm{ra}$, se os deuses existem ou não. Mais do que isso, ele tampouco pode estar certo do possível aspecto (idéa) que eles teriam, caso existissem às deveras. Sua hesitação em relação ao conhecimento dos deuses não é de todo inédita. Xenófanes já afirmara que ninguém (oútis anèr) pode adquirir conhecimento seguro (saphés) ou tornar-se sabedor (eidốs) de tudo quanto se refere aos deuses (amphì theōn). Ainda que viesse a deparar-se fortuitamente com a verdade, esse sequer o saberia, haja vista a opinião (dókos) impere a respeito de tudo (B34-DK) 19 . De modo similar, Melisso dizia não ser obrigado a pronunciar-se sobre os deuses (mè deîn apophaínesthai), já que deles não há nenhum conhecimento (gnōsin) (A1-DK). O que há de novo na sentença protagórica, e que depois há de ser absorvido pela tragédia de Eurípides, é a ênfase incontornável no sujeito: ela não exclui peremptoriamente a realidade dos deuses, como se tratasse de objeto inexistente, porém questiona a posição do sujeito em relação a tal objeto. Nos autores em que foi conservada, por diversas que sejam suas tradições, os termos relativos às funções cognitivas do sujeito sempre se fazem ouvir: "ser capaz de saber" (eidénai dýnasthai) e "julgar/decidir" (athrếsasthai) em Tímon (A12-DK); "eximir-se de decidir" (exaírō) em Platão; "ser capaz de dizer" (habeo dicere) ou de "saber com clareza" (habere quod liqueat) em Cícero;; "ser ignorante" (ágnōston) em Filodemo; "não saber" (mè eidénai) em Diógenes de Enoanda (A23-DK).

19 Alguns autores chegaram a sugerir que Protágoras herdou de Xenófanes seu pensamento sobre os deuses. Cf. MÜLLER, 1976, p. 317. 
Naturalmente, esse fato se conecta com a tese do homo-mensura e com o restante da doutrina de Prótagoras. De resto, ele também atesta a visão de Hegel, para quem a novidade da sofística em relação aos pré-socráticos consiste no retorno do pensamento sobre si mesmo (Rückkehr des Denkens in sich), ou seja, no cultivo dos mais diferentes pontos de vista subjetivos contra o primado então vigente do objeto absoluto (HEGEL, 1971, p. 404). Para Hegel, os sofistas priorizam a consciência do sujeito que conhece em detrimento do objeto conhecido (HEGEL, 1971, p. 405), antecipando eo ipso o princípio da modernidade (HEGEL, 1971, p. 404). Em relação aos deuses, esse princípio instaura o lluminismo grego, já que substitui a crença impensadamente aceita pela investigação racional: "já não se acredita, porém se investiga" (HEGEL, 1971, p. 410, tradução nossa) ${ }^{20}$. Conquanto essa explicação possa parecer abstrata e inteiramente dependente do sistema hegeliano, sua correção hermenêutica a respeito da teologia grega foi testada por Werner Jaeger, para quem os sofistas escrutinam pela primeira vez os problemas teológicos sob o prisma da antropologia e da psicologia: “Por fim, os sofistas foram os primeiros psicólogos, que também consideraram o fenômeno religioso sob essa perspectiva" (JAEGER, 1976, p. 43, tradução nossa) ${ }^{21}$. O caso de Protágoras é o mais emblemático a esse respeito, ainda quando o humanismo radical se faça presente nos demais autores. Depois de citar a tese do homo-mensura, Jaeger escreve acertadamente que é a partir dela que se deve entender a expressão "não posso saber" da sentença sobre os deuses, pois ela caracteriza a incognoscibilidade dos deuses e mostra que a crença neles se reduz a uma opinião individual (JAEGER, 1976, p. 65). Para ele, tal foi a tendência dominante daquele tempo, além do projeto de unir o conhecimento sobre os deuses com o reconhecimento do fato positivo da religião para o homem enquanto ser social, algo que se evidencia claramente no Mito de Prometeu, em Pródico e em Crítias (1976, p. 65).

\footnotetext{
20 Do original: es wird nicht mehr geglaubt, sondern untersucht .

${ }^{21}$ Do original: Endlich waren die Sophisten die ersten Psychologen, die das religiöse Phänomen auch von dieser Seite her ins Auge gefasst haben.
} 
Não é apenas a expressão "não posso saber" que, fazendo alusão à necessidade de aquiescência por parte do sujeito cognoscente, critica e inverte a posição pré-socrática; também a parte relativa ao aspecto dos deuses alude às inúmeras discussões travadas por Xenófanes e Heráclito (JAEGER, 1976, p. 64). Xenófanes pensa que, fossem os cavalos e bois dotados de mãos, desenhariam os deuses à sua imagem e semelhança (B15-DK), assim como os deuses dos etíopes são negros e têm nariz chato (B16-DK); ele critica Hesíodo e Homero, de forma bastante rude, por tudo de mal que atribuíram aos deuses (B11-DK) e louva o homem que, em um banquete, nada fala de gigantes, centauros e titãs, a que chama desdenhosamente de "invenções dos antigos" (plásmatōn tōn protérōn) (B2-DK). Em relação ao penúltimo ponto, algo similar se deixa ver em Heráclito: quando, exasperado, proclama que Homero deveria ser banido dos certames e açoitado (B40, 42-DK), provavelmente pensa em como o poeta descreveu os deuses. Contudo, enquanto esses pensadores condenam o antropomorfismo com base em um saber teológico que parecem possuir, Protágoras limita-se a suspender seu juízo. Como devia ocorrer na discussão sobre a existência dos deuses, é provável que ele também desenvolvesse aqui uma argumentação in utramque partem, mostrando a impossibilidade de sustentar uma opinião definitiva. Ele acredita não ser dado ao homem saber como os deuses são, pois muitos obstáculos (kōlýonta) interpõem-se em seu caminho. Entre eles, o sofista evoca imediatamente dois: a obscuridade da questão e a pequenez da vida humana.

\section{0 ataque à transcendência: empirismo e materialismo}

Cumpre salientar que Protágoras utiliza uma palavra relativa à "clareza" que se pode obter acerca desse assunto, fazendo com que tudo repouse novamente no indivíduo. Além de significar "incerto, obscuro e secreto", o adjetivo ádēlon é empregado para tratar de coisas "invisíveis", como aquelas que são objeto de certas correntes religiosas. Protágoras nega peremptoriamente que o homem possa ter conhecimento de tais coisas. 
Como os outros fragmentos sugerem, isso se dá porque ele é um pensador da imanência, que ataca todo o plano imaterial ou suprassensível. É neste sentido, outrora brevemente ressaltado por Untersteiner (2012, p. 59), que se deve compreender a sua posição sobre os deuses, a qual, a despeito da aparente serenidade, exala também a amargura de uma conclusão negativa. Para dizê-lo de outra maneira, não é o ataque à transcendência característica perfunctória de Protágoras, mas à própria essência de seu pensamento.

No âmbito da epistemologia e da psicologia, ele acredita que a alma seja formada exclusivamente por percepções sensíveis (aísthēsis) (A1DK). Nada há nela de divino ou transcendente, seja isso uma faculdade especial, como o noûs de Aristóteles e o "olho da alma" de Platão, seja isso uma origem divina, como pregavam as escatologias da época. Sua constituição é feita do mesmo elemento que compõe as coisas materiais. Hérmias relata que o sofista considerava o homem como limite (hóros) e instância decisiva (krísis) do que existe (tōn pragmátōn), e que existir significava para ele "cair sob os sentidos" (tà hypopíptona taîs asthếsesin), pois as coisas que não o fazem nem sequer existem nas formas do ser (en toîs eídesi tēs ousías) (A16-DK). Em primeiro lugar, trata-se assim de uma psicologia sensualista, que denega a existência de um elemento espiritual ou diverso das sensações. Em segundo, trata-se de uma ontologia simultaneamente empirista e especista, para a qual a existência está restrita à esfera sensível própria ao ser humano. Percepções que escapam aos nossos sentidos, como aquelas que são próprias à faixa de audição dos felinos, nem sequer existem. Sendo o homem a medida da realidade, só existe aquilo que ele pode perceber com seu acanhado aparato sensorial.

Sexto Empírico esclarece esses pontos ao explicar que, para Protágoras, o homem é formado por uma matéria em constante fluxo (hýlè rheustế). Desse fluxo material, feito mais de acréscimos (prosthếseis) que de perdas (apophorếseis), geram-se as sensações (aisthếseis), as quais se alteram conforme a idade, a natureza, as condições corpóreas (kataskeuàs tōn somátōn) e demais disposições (diathéseis), como o sono e a vigília. Todos esses fatores contribuem para formar a percepção do indivíduo, verdadei- 
ro critério (kritếrion) da realidade ${ }^{22}$. Dito de outro modo, o fundamento (lógos) de tudo quanto existe (pántōn tōn phainoménōn) não se acha em outro lugar, a não ser nessa matéria em fluxo. Na opinião de Sexto, por postular (títhēsi) como existente apenas aquilo que aparece a cada pessoa (hekástō), na infinita singularidade de sua mutável constituição material, Protágoras introduz o relativismo (tò prós ti). À parte o explícito materialismo e as inegáveis reminiscências de Heráclito - as quais devem ser tidas por autenticamente protagóricas, uma vez que Platão, assim no Crátilo como no Teeteto, insistiu no liame entre o heraclitismo e o relativismo - isso significa dizer que a alma não possui nenhuma soberania espiritual ou cognitiva em relação à matéria: ela se molda ao que o fluxo material lhe impõe ${ }^{23}$. Essa desalentadora passividade do homem na formação de suas percepções e de sua posterior avaliação da realidade retorna em Górgias e, quando contraposta à filosofia de Platão e Aristóteles, que postulam mutatis mutandis a existência de princípios lógicos, de faculdades e de seres não sujeitos ao sensível, revela-se uma tendência da sofística. Para Protágoras, a matéria é tudo o quanto a alma humana pode conhecer. Sobre as coisas obscuras que possam existir - e eis que aqui Sexto emprega a palavra adélōn, remetendo talvez o leitor à sentença sobre os deuses - deve-se suspender o juízo (A14-DK).

A vida humana está destarte confinada às percepções do sujeito e aos estados da matéria que estão em correlação com as disposições corpóreas. Este fato já assinala um ataque a certas noções transcendentes que então

22 Embora a palavra kritếrion pertença ao vocabulário conceitual do ceticismo, Platão já a empregara no Teeteto (178b6) para falar da sentença de Protágoras.

${ }_{23}$ Há por trás dessa ideia uma mescla de doutrinas que remonta a Demócrito e a Empédocles, ambos os quais compreendem a percepção através da transmissão material de corpúsculos. Em Górgias, cuja doutrina deve muita coisa a Empédocles, seu suposto mestre, aparece a mesma passividade da alma diante da percepção sensível: no quarto argumento do Elogio de Helena (16-17), a digressão sobre a visão estabelece que, à vista de algo amedrontador ou prazeroso, sentimos a emoção correspondente, sem que qualquer faculdade anímica possa fazer frente a tal emoção. Esse modelo de passividade é fundamental para que a sofística funcione. Em parte, Platão e Aristóteles só têm sucesso na refutação dos sofistas porque postulam que a razão é soberana em relação às emoções. 
existiam: sem admitir a existência de fenômenos diferentes dos sensíveis, tampouco de uma faculdade específica que poderia captá-los, Protágoras afirma a imanência e a redução do sujeito à esfera sensível. Essa postura é coerentemente mantida no campo da matemática, que ao menos desde os Pitagóricos fora tomada como exemplo de um conhecimento a um só tempo seguro e essencial, que ainda se ligava às crenças órficas sobre a purificação e a imortalidade da alma (KAHN, 2007, p. 38). No bojo de uma discussão sobre o estatuto platônico dos entes intermediários e da supérflua duplicação das ciências sensíveis e inteligíveis, na Metafísica, Aristóteles escreve que Protágoras refuta os geômetras ao sustentar que o círculo sensível encontra a tangente em mais de um ponto. A partir do contexto da discussão, pode-se concluir que essa refutação se dá através da firme negação de um plano não sensível: o desenho do círculo e da reta, percepções sensíveis seguras, revela a nulidade do princípio geométrico, pois prova que a reta toca o círculo em vários pontos (B7-DK). E Filodemo reporta, a esse propósito, que Protágoras julgava incompreensíveis (ágnōsta) os objetos da matemática e insatisfatórias (ouk arestás) as expressões (léxeis) que tratam deles (B7a-DK). Ou seja, sua perspectiva ontológica é a de um materialismo radical que recusa todo o conhecimento ou entidade minimamente abstrata. Aqui talvez fosse o caso de dar razão a Bárbara Cassin (1999, p. 14), quando escreve que os sofistas padecem de uma hýbris fenomenológica.

Essas considerações já esclarecem por que a obscuridade (adēlótēs) assombra a questão teológica fundamental. O outro ponto é a pequenez da vida humana. Sobre isso, gostaria de propor a modificação da tradução usual de brachýs, adotada pelos intérpretes citados na bibliografia. Quando se trata de designar quantidades, este termo significa "pequeno, curto, breve". Se tal devesse ser sua tradução no fragmento de Protágoras, então o sofista negaria ao ser humano o saber teológico por conta da breve extensão cronológica da vida. Embora isso seja possível, nada há que o confirme, a não ser a longa tradição de tradução. O outro sentido de brachýs parece mais apropriado: quando aplicado qualitativamente, 
tal adjetivo designa algo "ínfimo, humilde, de pouca monta". O LiddellScott atesta o uso em Sófocles, contemporâneo de Protágoras; com esse sentido, o adjetivo aplica-se a pessoas e a coisas. Note-se que, com isso, não estou a dizer que as demais traduções são errôneas, mas apenas que a ênfase em outro dos sentidos dicionarizados da palavra brachýs parece fazer mais sentido em confronto com os demais fragmentos. Por força do ataque à transcendência mencionado, baseado na flagrante limitação das capacidades cognitivas do homem, este deve ser o sentido da sentença protagórica. A brevidade da vida humana constitui, claro, um tipo de pequenez; entretanto, pensada em sentido mais amplo, a pequenez possui outros elementos. A obscuridade da questão ocorre não apenas porque a vida humana seja cronologicamente curta, mas porque ela é sobremodo ínfima para resolver tamanho problema. Sujeita ao devir da matéria e reduzida à medida do homem, ela não dispõe de nada que a alce para além do plano material, onde os deuses ou outros entes poderiam subsistir. A meu ver, essa ligeira modificação da tradução lança nova luz sobre os fragmentos de Protágoras e permite interpretar melhor seu pensamento.

\section{Homo-mensura e discursos duplos}

No mesmo sentido da constatação da pequenez do homem, pode ser lida a sentença sobre a medida das coisas: "O homem é a medida de todas as coisas, daquelas que são enquanto/como são, daquelas que não são enquanto/como não são" (B1-DK, tradução nossa).

Certamente há nela um tom triunfal que proclama o domínio do homem sobre todas as coisas com as quais ele se depara (chrếmata), como evidenciado pela palavra métron, que significa, segundo Untersteiner (2012, p. 134), o domínio gnosiológico sobre algo. Por outro lado, há o reconhecimento da pequenez das forças do homem quando se trata de saber o que de fato existe e o que isso vem a ser, já que a sentença submete o conhecimento e a própria existência das coisas - sejam elas as 
coisas de que fazemos uso ( $p$ rágmata), sejam elas as nossas experiências fenomênica (UNTERSTEINER, 2012, p. 134) - à reles medida humana. O próprio uso de chrếmata ao invés de ónta está aí para mostrar que o sofista se refere a coisas concretas, em clara crítica à ontologia parmenídica, e não às coisas tais como poderiam ser em si mesmas (VERSENYI, 1976, p. 294). Ou seja, este termo deve ser tomado em sentido conceitual, como uma indicação de que os próprios entes (ónta) são na verdade apenas as coisas (chrếmata) que cabem na medida do homem. É altamente significativo que Platão, ao citar esse pensamento e ao exprimir sua impressão sobre o livro de Protágoras, insista em dizer (Tht. 161c7; 166a) que o tom do sofista é desdenhoso (kataphronōn), usando a mesma palavra que, em uma possível alusão de Eurípides a Protágoras (C4-DK), aparece conectada com os discursos demolidores (katabállontes lógoi) que compõem o subtítulo de seu livro sobre a verdade ${ }^{24}$. Os dois reconhecem que Protágoras avança para uma crítica avassaladora que destrói pretensões gnosiológicas demasiado prepotentes. É como se Protágoras, ante o otimismo de parte da filosofia pré-socrática, que supunha possível o conhecimento do Ser, alertasse para o fato de que o homem, carente quer de faculdades cognitivas transcendentes, quer de um auxílio divino, está triste e irremediavelmente entregue a si mesmo ${ }^{25}$. Aqui não importa decidir se se trata do homem individual ou da humanidade como espécie,

\footnotetext{
${ }^{24}$ Katabállein significa "derrubar, nocautear, pôr abaixo com uma arma" etc. Segundo Heitsch (1976, p. 299), o termo era uma metáfora retirada do âmbito da luta para expressar a refutação dialética, o que se pode evidenciar em Eurípides, Platão, Demócrito etc. Este autor também comenta (1976, p. 299) que ele foi ligado pela tradição aos Apopyrgízontes lógoi de Diágoras e aos Hyperbállontes lógoi (Discursos vitoriosos) de Trasímaco. Sobre a tradução do título do livro de Diágoras, há várias possibilidades: o termo contempla a ideia de "fortificar" e pode ser traduzido como "discursos fortificantes". Todavia, abarca também a ideia de "sitiar" e de "derrubar algo/ alguém de uma torre". Um último sentido envolve a ideia de "baú" e, assim, de que os discursos pudessem ser secretos. Cf. JANKO, 2001, p. 7. O importante é que, afora o primeiro sentido, o qual talvez possa ser descartado por causa da preposição apó, todos os demais contêm intento destrutivo, ou pelo menos a ideia de que se trata de algo que não se pode dizer coram populo.

25 Digo de parte da filosofia pré-socrática, pois, porque esse problema parece ter sido antevisto por expoentes desse período da filosofia grega, como argumentado em seguida. Para um panorama das posições pré-socráticas que valorizam o subjetivismo, o relativismo e o ceticismo, confrontando assim a perspectiva de Hegel, impõe-se ainda o estudo clássico de Mondolfo (1968).
} 
uma questão que se discute desde Platão (Tht.152a; 166d; Crat. 385e); em ambos os casos há uma restrição e uma consequente demolição de várias possibilidades epistêmicas. Nesse realismo algo trágico parece consistir na virada epistemológica e linguística da sofística.

Com a inversão de seu triunfalismo usual, a sentença do homo-mensura passa a fazer eco a uma longa tradição grega que sublinha a abissal diferença dos homens em relação aos deuses e a precariedade de sua condição. Ela recorda a pequenez de nosso aparato cognitivo e alia-se à consciência pagã da efemeridade da vida humana. A fim de exemplificar esse fato, restrinjo-me aqui a alguns pontos essenciais.

Em Homero e Hesíodo encontra-se o início dessa consciência. Para Homero, o homem está entregue a deuses caprichosos que se regozijam com o contemplar de suas dores. Eventos grandiosos e terríveis, como a Guerra de Troia, são levianamente tecidos por razões estéticas, a fim de que haja matéria para os poetas congratularem os deuses. "Os deuses decidiram. Fiaram a catástrofe dos homens para a poesia existir um dia" (OD. 8, 579-580), declara o rei Alcínoo sobre Troia. E sua frase ecoa o que Helena diz de si e de Páris, na llíada $(6,358)$, a saber, que os deuses Ihes impuseram fado sinistro para que sejam tema de vates vindouros. Para Príamo está também claro que a culpa da guerra repousa sobre os deuses, não sobre Helena (Il. 3. 163-166); ela é a realização da decisão de Zeus, como o poeta anuncia no preâmbulo (Il. 1. 5). Ademais, em celebérrimo trecho ressalta Homero como a vida humana é efêmera, comparando-a ao nascer e perecer das folhas das árvores; como elas, os homens são derrubados pelos ventos e substituídos a cada estação (Il. 6. 145-150). Sobre o conhecimento, por sua vez, ressalta que apenas as divindades como as Musas conhecem a verdade e a falsidade das coisas; aos homens resta apenas o "rumor" (kléos) (Il. 2, 484-493). Dado que Protágoras tenha comentado Homero (29; 30B-DK), é verossímil supor que tais temas the fossem familiares. Já Hesíodo - cuja história especulativa sobre as idades da humanidade ecoa na sofística quando se trata de pensar a religião (Crítias e Pródico), devendo ter desempenhado algum papel no escrito protagórico 
Sobre a condição original - estende a sofrida condição do camponês beócio a toda a humanidade, pintando o homem como a um humilde comedor de pão preso a uma época marcada por sofrimento e trabalho duro, a Idade do Ferro. Ele diz que preferia não ter nascido, a ter de viver agora nessa Idade em que os deuses dão duras angústias aos mortais e bens que vêm misturados aos males (Op. 174-179). De forma talvez mais evidente que em Homero, o homem de Hesíodo está entregue a forças que lhe são alheias e superiores, quando não declaradamente hostis.

No período pré-socrático, essa drástica diferença entre a condição humana e a divina assume contornos epistemológicos, posteriormente aprofundados pelos sofistas. Já nos fragmentos de Xenófanes acima citados, isso se deixa entrever, uma vez que neles transparece a ideia de que o homem carece de um saber inequívoco e está confinado à aparência. No poema de Parmênides, por sua vez, há uma verdade redonda (eukykléos alétheiē) e perfeita disponibilizada pelos deuses a seletos mortais. Como um poeta inspirado, o autor do poema é passivamente conduzido (me phérousin) até ela depois de abandonar "a senda normal dos homens" (ê gàr ap'anthrốpōn ektòs pátou). Mas ele deve também aprender aquilo que vale para a maioria das pessoas, ou seja, as opiniões dos mortais nas quais não subsiste nenhuma certeza verdadeira (pístis alēthếs) (B1-DK). À maioria dos seres humanos, como esclarecido na sequência do poema, resta apenas um mundo de ilusões verbais - a famosa expressão kósmon emōn epéōn apatēlón, que fará carreira na retórica de Górgias (Hel. 10; B23-DK) e de Platão (Phdr. 261e6-8) - as quais constituem a base de suas explicações físicas do cosmo. Assim, sem o auxílio dos deuses, o conhecimento que o homem fabrica resume-se a um saber próprio dos mortais (brotōn dóxas) que mais ilude do que ilumina, algo que os paradoxos de Zenão, depois retomados por Górgias (ZELLER, 1893, p. 80), demonstram a respeito de crenças as mais seguras, como a crença no movimento. $O$ eleatismo exibe já uma consciência, portanto, dos limites do aparato cognitivo humano.

A diferença entre o saber divino e o humano também aparece em Heráclito, quando ele afirma que os homens emitem diversos juízos de 
valor sobre as coisas, tomando-as por belas e feias, justas e injustas etc., ao passo que os deuses as concebem de outro modo (B102-DK). Daí se depreende que as coisas não se apresentam ao homem tais como são, mas em fragmentos de realidade potencializados por uma apreensão (lógos) errônea e particular (B1-DK), que gera o império das múltiplas opiniões. $\mathrm{E}$ a isso se segue uma série de reprimendas contra a maioria $\mathrm{e}$ a sua falta de entendimento (B17; 19; 29; 34; 72-DK); um aviso para que não se levantem vãs hipóteses sobre coisas supremas (B70-DK); e um julgamento taxativo, por fim, que concebe todas as opiniões humanas como meros jogos de criança (B47-DK). Heráclito, em suma, é atento à relatividade do saber humano. A diferença entre a realidade e a percepção particular do homem, finalmente, adquire plena consciência na teoria atomista, quando Demócrito, depois de dizer que a verdade jaz em um abismo (B117-DK), reconhece que as cores, os cheiros, os sons etc. são apenas convenções humanas (B9-DK), i.e., que o homem está afastado da realidade (B6-DK). Nessa ideia está o gérmen que fará florescer a dicotomia sofística entre nómos e phýsis. Outros fragmentos não deixam dúvidas sobre a forte dose de epistemologia falibilista ${ }^{26}$ que o concidadão e contemporâneo de Protágoras desenvolveu (B7; 8; 10; 11-DK). Daí talvez decorra a sua concepção sobre a precariedade da vida humana, que ele julga frágil, efêmera e prenhe de cuidados (B285-DK).

A partir desses testemunhos percebe-se como os pré-socráticos reconhecem os limites do conhecimento humano em comparação com o saber divino. No desabrochar da sofística, essa consciência é diligentemente desenvolvida. Como movimento, a sofistica não só absorve a ideia de contradição e de relativismo que a cultura grega acalentara desde Homero (UNTERSTEINER, 2012, p. 50; VERSENYI, 1976, p. 296; DHERBEY, 1986, p.

\footnotetext{
${ }^{26}$ Não me parece errôneo aplicar este termo contemporâneo ao caso grego. Em sentindo estrito, trata-se de um conceito predominantemente ligado à filosofia de Popper. Em sentido amplo, todavia, ele designa toda a epistemologia que, ao contrário do fundacionismo, defende que o saber humano é falho ou relativo, sendo-nos impossível atingir verdades eternas e absolutas. Para essa diferença, Cf. DUTRA, 2005.
} 
18), como intensifica as críticas ao aparato cognitivo do homem divisadas parcialmente por esses autores e, no que se refere à vida, ressalta o seu lado mesquinho e fugaz. O humanismo radical dos sofistas enseja duplo efeito: por um lado, proclama o domínio do homem diante da realidade e exalta sua força e astúcia; por outro, admite que o seu saber e a sua vida são limitados e inseguros. As sentenças de Protágoras sobre os deuses e sobre a medida constituem o exemplo mais acabado de um pensamento que, refletindo sobre o homem, descobre tanto seu poder quanto suas falhas ${ }^{27}$. Mas há outros autores onde isso se deixa ver. Sobre a vida, por exemplo, Antifonte escreve que ela "não tem nada que extrapole o limite, nada de grandioso, nem de solene, mas todas as coisas são pequenas, frágeis, breves e misturadas com grandes dores (B51-DK Trad. Luís F B. Ribeiro)". Já no que toca ao conhecimento, Górgias frisa como a condição humana se resume ao mundo da aparência e aos caprichos da oportunidade.

Pois, certamente, se todos, acerca de tudo, tivessem a lembra das coisas passadas, a noção das presentes e a previsão das futuras não seria igualmente igual o discurso para aqueles aos quais nesse momento nem lembrar do passado nem investigar o presente nem predizer o futuro é fácil; de maneira que, acerca da maior parte das coisas, a maioria a opinião como conselheira apresenta a alma. Mas a opinião, sendo

\footnotetext{
${ }_{27}$ 'It is Protagoras' historical position, i.e. that he radicalized and unified these views [a saber, as visões de pensadores como Xénofanes e Heráclito, que relativizam o julgamento meramente humano] in the midst of and in opposition to natural philosophy's search for absolute, unchanging, universal first principles and substances, that gives his relativism the status of a much needed reform. While natural philosophy wanted - and thought itself capable of - getting away from what is merely human, relative, and conditioned, Protagoras in effect declared that this attempt is neither fruitful nor desirable (VERSENYI, 1976, p. 297). Para Müller (1976, p. 320), o agnosticismo empirista de Protágoras e principalmente o argumento sobre a brevidade da vida são exemplos de uma tendência epistemológica geral que enfatiza os limites da capacidade humana de conhecer (Begrenztheit der menschlichen Erkenntnisfähigkeit), como se vê em Empédocles e Hipócrates. Exceto pelo fato de que ele toma o termo brachýs em sentido exclusivamente quantitativo, sua opinião é correta e aumenta a lista de autores descrita brevemente acima. Taureck (1995, p. 100) concorda que o fragmento sobre os deuses descreva uma limitação (Beschränkung) da capacidade humana de conhecer.
} 
vacilante e instável, envolve em sorte vacilante e instável os que se servem dele (Hel. 11).

Essa passagem possui tom similar à sentença do homo-mensura e configura testemunho histórico da aguda consciência epistemológica dos sofistas, pois em ambos os casos se descrevem as restrições da condição humana no campo do conhecimento. Depois de atacar o Ser de Parmênides e qualquer forma de abstração - como Górgias faz no tratado Sobre o não-ser e Protágoras em sua Verdade ou discursos demolidores $^{28}$ - resta apenas o mundo ilusório das opiniões, sobre o qual o sofista assenta sua atividade profissional e teórica. É nesse sentido que se conectam o termo brachýs e a ideia de medida.

Ademais, mesmo que o homem seja responsável por proclamar aquilo que existe, posição que decerto possui algum privilégio, resta ainda o problema de saber qual dos discursos proclamados é o verdadeiro. Ou seja, o fragmento que assevera a existência de dois discursos contrários (antikeiménoi lógoi) sobre cada objeto de discussão, a arte da antilogiké, também deve ser entendido nessa toada: ele torna a situação supradita ainda mais dramática. Protágoras não apenas julgava que havia dois discursos opostos sobre cada tema imaginável (perì pantós) (B6a-DK), como também que era possível, com a devida habilidade retórica, fazer com que o discurso inicialmente mais fraco (tòn hếttō lógon) se tornasse vencedor (kreîtō poeîein) (B6b-DK). Ele é o primeiro a afirmar que tudo é verdade (pánta alēthế eînai) (A1-DK) e que é impossível haver contradição (ouk éstin antilégein), um problema assaz espinhoso que Platão menciona no Eutidemo (286bc), relacionando-o a Protágoras, e enfrenta no Sofista através do enigmático parricídio de Parmênides. Isso significa que não existem verdades objetivas, para além daquilo que os sujeitos percebem,

28 "Schematicamente si potrebbe forse dire che mentre Empedocle ed Anassagora cercavan di raggiungere un compromisso tra l'Aletheia e la Doxa de Parmenide, la Doxa stessa diviene per Protagora l'única Aletheia (GIGON, 1985, p. 436). O mesmo se pode dizer de Górgias. 
que assegurem a correção de um discurso. Elaborada a partir das precárias percepções de um indivíduo, que se modificam ao sabor de suas disposições corpóreas, é a verdade tão-somente o predomínio retórico, adstrito aos limites do espaço e do tempo (kairós) ${ }^{29}$, do discurso defendido com maior persuasão. O homem não tem acesso a nenhum plano além das sensações e dos discursos, ambos os quais se revelam passíveis de contraposição. No que tange aos deuses, a propósito, o levantamento de duas possibilidades contrárias dá a entender que aquilo que se seguia à sentença inicial, como dito, era precisamente uma argumentação in utramque partem que deveria evidenciar como as duas posições, o ateísmo e o teísmo, são igualmente sustentáveis. O fragmento pode ser compreendido como o anúncio programático da investigação que viria a seguir, e isso é tanto mais verdadeiro se, ao invés de pertencer a um livro autônomo, ele compunha a seção de abertura das Antilogias (UNTERSTEINER, 2012, p. 37) 30.

Antes de findar essa discussão, é mister discordar em um pormenor de Untersteiner, que tenta compreender os dissoì lógoi de forma positiva e redimir assim o caráter destrutivo da tese de Protágoras. Sua opinião sobre a existência de dois planos de verdade parece exagerada. Para ele (2012, p. 95), há um primeiro momento em que a percepção do indivíduo é incontestavelmente verdadeira e o relativismo então se impõe. Dado

\footnotetext{
29 Segundo Diógenes Laércio (A1-DK), Protágoras teria sido o primeiro autor a definir os tempos verbais e a salientar a força do momento oportuno (tèn dýnamin toû kairoû), contribuindo assim para as discussões dialéticas, por um lado, e dando à luz o gênero erístico, por outro, uma vez que se concentrava mais nas palavras do que no conteúdo do pensamento. Ele também teria sido o primeiro autor a ensinar como elogiar e censurar a mesma pessoa, o que é uma grande evidência de seu raciocínio antilógico.

30 A expressão "anúncio programático" é uma alusão a uma frase de Müller (1976, p. 315): "in dem programmatischen Anfangssatz seiner Schrift perì theōn". Sobre o conteúdo antilógico: "Come già accenato, essa [a sentença sobre os deuses] permette due conclusioni. Dal punto de vista tematico, essa riguarda due problemi: l'esitenza e la forma degli dèi. L'aporia expressa nella frase introdutiva deve venire fondata da um punto di vista metodico. Protagora doveva perciò sviluppare i pro ed i contro riguardo l'esistenza degli dèi, quindi i pro ed i contro sulla loro forma umana (solo questa, infatti, doveva essere in discussione) ed infine concludere che noi, come uomini, non siamo in condizione di pervenire ad una sicura decisione" (GIGON,, 1985, p. 438). Concordando com Gigon, discordo de outra opinião de Müller (1976, p. 321), para quem não há provas de que o conteúdo do livro fosse crítico.
} 
que a promulgação universal desse fato acabaria com a existência de mestres e discípulos, bem como de opiniões melhores e piores, ele sustenta que há para Protágoras um segundo momento onde o sofista, com sua habilidade retórica, pode conduzir alguém de uma posição gnosiológica inferior, através de um processo educativo, para uma posição superior. Assim Untersteiner compreende a passagem do discurso inferior para o superior: como a passagem de uma avaliação cognitiva da realidade mais precária para outra mais perfeita. O principal problema dessa interpretação é que ela se arrima exclusivamente no Teeteto de Platão. Embora não se deva descartar que tal diálogo contenha algumas posições de Protágoras, é por demais arriscado tomá-lo por um retrato fiel, quando se sabe da liberdade que Platão empregava na composição de suas obras ${ }^{31}$. O sentido mais comezinho da expressão tòn hếttō lógon kreîtō poeîein, tal como preservado por Aristófanes e exemplificado nas discussões do Eutidemo, revela tão-somente o seu caráter erístico e a sua pressuposição de que a verdade é relativa a cada sujeito. Tentar encontrar um emprego epistemológica e educativamente significativo para isso significa cair na falácia do ad captandam benevolentiam. Noutras palavras, tal emprego simplesmente não condiz com um autor que, ao lado do termo "verdade", escolheu para título de seu mais importante livro uma expressão retirada do contexto da luta e, portanto, com inequívocos traços destrutivos.

\footnotetext{
31 Sobre isso, penso em dois testemunhos. Górgias, ao ler o diálogo homônimo, teria dito que Platão era exímio em satirizar (iambízein) os outros (A15a-DK). E Sócrates, depois de ler o Lísis, teria dito: "Por Héracles! Quantas mentiras este rapaz me faz dizer!" (D.L. 3, 34). A meu ver, isso revela a grande liberdade literária de Platão e seu desdém para com os fatos históricos (como também sugere o Menexeno), e confirma o juízo de Aristóteles, na Poética (1447b9-13), segundo o qual os diálogos são um tipo de mimese. Dizer isso significa, para Aristóteles, que eles não se ocupam em descrever as coisas que de fato aconteceram, como faz a história, mas sim como elas poderiam acontecer (àn génoito) conforme a verossimilhança e a necessidade. Outros autores antigos, como Longino e Proclo, também reconheceram a dívida de Platão para com a poesia. Cf. ENGLER, 2017. Sendo assim, julgo precipitado tomá-lo como fonte absolutamente segura da expressão do pensamento de Protágoras.
} 


\section{Considerações finais}

A partir dessas reflexões pode-se compreender mais acuradamente o agnosticismo de Protágoras. Para frisar sua unidade com a doutrina do homo-mensura e do dissòs lógos, é correto falar em agnosticismo antilógico. A isso cumpre adicionar a reflexão sobre a precariedade da vida humana, que confere os contornos finais à doutrina de Protágoras. Não se trata, por conseguinte, de ateísmo, como julgam as fontes que confundem Protágoras com Diágoras de Melos, mas de um agnosticismo que parece antecipar duas posições filosóficas posteriores: a cética, também arrimada em uma epistemologia de cariz destrutivo e na equipolência de argumentos contrários; e a moderna, a qual, como Hegel explica, toma o pensamento do sujeito como princípio do real ${ }^{32}$. Cícero entendeu-o bem, ao dissociar Protágoras de Teodoro de Cirene e de Diágoras, afirmando que ele não era propriamente ateu, já que para ele nenhuma das opiniões era clara, nem que os deuses existiam (nec esse deos), nem que não existiam (nec non esse) (ND 1. 117).

Cabe dizer uma última palavra sobre a gênese dessa posição. Filóstrato sustenta que Protágoras teria aprendido o seu agnosticismo dos ensinamentos dos magos persas, por quem fora educado quando menino (A2-DK). Segundo ele, esses sacerdotes negavam publicamente a existência dos deuses, a fim de que as pessoas não pensassem que seu poder provinha de uma esfera divina; entretanto, aceitavam a sua realidade em privado. Essa

\footnotetext{
32 Gigon (1985, p. 431) também argumenta que não se trata de ateísmo, mas que Protágoras se limitava a constatar que as forças cognitivas do homem não podem atingir conclusão definitiva sobre a existência e a forma da divindade. Segundo Hegel: "Wir sehen, dass Protagoras große Reflexion hat. Dies ist also die Reflexion auf das Bewusstsein, die im Protagoras selbst zum Bewusstsein gekommen ist. Dies aber ist die Form der Erscheinung, zu der Protagoras kam und die von den späteren Skeptikern wieder aufgenommen ist (HEGEL, 1971, p. 434). Embora reconheça que o princípio da modernidade seja o subjectum, Heidegger (1972, p. 96) tenta mostrar que se trata de algo diverso do que pensaram os antigos e tacitamente critica, assim, a posição de Hegel. Para ele, a sofística só é possível sobre o solo da interpretação grega do ser como Anwesen e da verdade como Unverborgenheit, e isso destoa claramente do princípio moderno - do cogito cartesiano - que pressupõe a representação. Na sofística, afirma Heidegger (1972, p. 98), o subjetivismo é impossível, e a ideia protagórica da medida deve ser entendida como o reconhecimento da limitação do desvelamento através da percepção da presença. Naturalmente, neste espaço é impossível discutir com profundidade essa tese.
} 
visão pressupõe os disfarces que os sofistas eram obrigados a assumir para que não fossem sumariamente julgados pela opinião pública, o que, como sublinhado em nota, concorda com uma das possíveis leituras do mito de Prometeu. Ela não é errônea porque há razões para duvidar dessa educação persa ${ }^{33}$, nem porque tenta salvar o sofista da infâmia do ateísmo. Ela o é porque ignora que o agnosticismo antilógico concorda com o restante das ideias de Protágoras. Ou seja, se as discussões acima procedem, resulta claro que a posição teológica de Protágoras não é aleatória, senão que exibe harmonia inconsútil com os demais fragmentos de sua lavra.

Mais do que isso, ela representa um dos pontos mais altos do lluminismo de que os sofistas foram porta-vozes, pois reconduz com acerto os dois mais prementes problemas teológicos, a existência e a forma dos deuses, ao âmbito da capacidade cognitiva do sujeito. Ao fazê-lo, ela descortina um grande limite do conhecimento humano: a ideia de que, independentemente da resposta, a questão sobre a existência divina é sempre uma questão humana, demasiado humana. Mesmo quando enovelada pela veneranda antiguidade dos mitos ou defendida pela força das instituições, essa questão deve sempre ser posta e respondida por um ser humano, pois é ele quem deve também decidir, ao fim e ao cabo, que os mitos são veneráveis ou que as instituições precisam ser respeitadas. E aqui, ecoando a longa tradição grega que reconhece a precariedade humana, tradição iniciada pela épica e convertida em crítica epistemológica pelos pré-socráticos, Protágoras conclui que a vida humana não permite muita clareza. Como Homero, Hesíodo e os pensadores pré-socráticos acima discutidos, Protágoras ressalta o lado trágico e efêmero da condição humana, elevando assim a consciência individual grega a um novo patamar. Para ele, essa condição drasticamente imanente nos lança em uma batalha de discursos que carecem de um critério externo de veracidade e, destarte, estão sujeitos ao relativismo das percepções individuais, do

33 Para a discussão do testemunho de Filóstrato: Müller, 1976, p. 339; Gigon, 1985, p. 429. 
momento oportuno e da persuasão retórica. Em suma, Protágoras mira alto nos deuses e encontra, no fundo, o homem dilacerado pelas dúvidas impostas por sua ínfima existência ${ }^{34}$.

\section{Referências}

ANTIFONTE. Testemunhos, fragmentos, discursos. Tradução Luis Felipe Bellintani Ribeiro. São Paulo: Loyola, 2009.

ARISTOPHANES. Frogs. Oxford: Oxford University, 1997. Edited with introduction and commentary by Kenneth Dover.

ARISTOPHANES. Clouds, wasps, peace. Edited and translated by Jeffrey Henderson. Cambridge: Harvard University, 1998.

ARISTÓTELES. De arte poetica liber. Oxford: Typographeo Clarendoniano, 1965. Recognovit brevique adnotatione critica instruxit Rudolfus Kassel.

BAILLY, A. Dictionnaire Grec-Français. Paris: Hachette, 2000. Rédigé avec le concours de E. Egger, nouvelle édition revue par L. Séchan et P. Chantraine.

BRISSON, L. Les Sophistes. In: CANTO-SPERBER, M. (org.). Philosophie grecque. Paris: PUF, 1991. p. 89-119.

CANTO-SPERBER, M. (org.). Philosophie grecque. Paris: PUF, 1991.

CASSIN, B. Aristóteles e o logos: contos da fenomenologia comum. Tradução de L. P. Rouanet. São Paulo: Loyola, 1999.

CICERO. De natura deorum academica. Translation H. Rackham. Cambridge: Harvard University, 1956.

CLASSEN, C. J. (hrsg.). Sophistik. Darmstadt: Wissenschaftliche Buchgesselschaft, 1976.

DHERBEY, G. Os sofistas. Lisboa: Edições 70, 1986.

DIELS, H.; KRANZ, W. I Presocratici: a cura di Giovanni Reale. Milano: Bompiani, 2012.

DODDS, E. R. Los griegos y lo irracional. Madrid: Revista de Occidente, 1960.

34 Gostaria de agradecer aos dois pareceristas anônimos, que sugeriram importantes melhorias ao artigo, e ao meu colega e amigo, Prof. Dr. Udo B. Moosburger, pelas relevantes discussões sobre os problemas da tradução. 
DUPRÉEL, E. Les sophistes: Protagoras, Gorgias, Prodicus, Hippias. Neuchatel: Éditions du Griffon, 1980. https://doi.org/10.2307/291814

DUTRA, L. H. A. Oposições filosóficas: a epistemologia e suas polêmicas. Florianópolis: UFSC, 2005.

ENGLER, M. R. Zu Platons künstlerischer Bestimmung der Philosophie: die Dialoge als höchste Form von Dichtung. Archai, Coimbra, n. 19, p. 93-129, 2017. https://doi.org/10.14195/1984-249x 194

ENGLER, M. Secularização e praticidade: a poética de Aristóteles em sua relação coma teoria da arte grega e com a filosofia do trágico. 2016. Tese (Doutorado em Filosofia) - Programa de Pós-Graduação em Filosofia, Centro de Filosofia e Ciências Humanas, Universidade Federal de Santa Catarina, Florianópolis, 2016. https://doi.org/10.19177/prppge.v4e720114-9

EURIPIDES. Bacchae, Iphigenia at Aulis, Rhesus. Edited and translated by David Kovacs. Cambridge: Harvard University, 2002. https://doi.org/10.1093/ oseo/instance.00185384

EURIPIDES. Fragments: Aegeus-Meleager. Edited and translated by Christopher Collard e Martin Cropp. Cambridge: Harvard University, 2008. https://doi. org/10.33776/ec.v15io.1174

GIGON, O. Il libro " Sugli Dèi » di Protagora. Rivista di Storia della Filosofia, [s. l.], v. 40, n. 3, p. 419-448, 1985.

GOMPERZ, T. Los pensadores griegos: historia de la filosofia de la antiguedad. Buenos Aires: Guarani, 1952.

GÓRGIAS. Elogio de Helena. Tradução de Maria C. de Miranda N. Coelho. São Paulo: USP, 1999. (Cadernos de Tradução, n. 4).

GÓRGIAS. Reden, fragmente und testimonie. Herausgegebn mit Übersetzung und Kommentar von Thomas Buchheim. Hamburg: Felix Meiner Verlag, 1989.

GUTHRIE, W. K. C. Os sofistas. São Paulo: Paulus, 1995.

HEGEL, G. W. F. Vorlesungen über die Geschichte der Philosophie I. Frankfurt am Main: Suhrkamp, 1971.

HEIDEGGER, M. Holzwege. Fünfte Auflage. Frankfurt am Main: Vittorio Klostermann, 1972.

HEITSCH, E. Ein Buchtitel des Protagoras. In: CLASSEN, C. J. (hersg.). Sophistik. Darmstadt: Wissenschaftliche Buchgesselschaft, 1976. p. 298-306. 
HEMMENWAY, S. Sophistry exposed: Socrates on the unity of virtue in Protagoras. Ancient Philosophy, [s. l.], v. 16, n. 1, p. 1-23, 1996. https://doi. org/10.5840/ancientphil199616113

HESIOD. Theogony, works and days, testimonia. Edited and translated by Glenn W. Most. Cambridge: Harvard University, 2006. https://doi.org/10.1007/ S12138-009-0055-0

HOMERO. Ilíada. Tradução de Haroldo de Campos. São Paulo: ARX, 2003.

HOMERO. Odisseia. Tradução de Trajano Vieira. São Paulo: 34, 2014.

JAEGER, W. Die Theorien über Wesen und Ursprung der Religion. In: CLASSEN, C. J. (hersg.) Sophistik. Darmstadt: Wissenschaftliche Buchgesselschaft, 1976. p. 38-67.

JANKO, R. The derveni papyrus ("Diagoras of Melos, Apopyrgizontes Logoi?"): a new translation. Classical Philology, [s. l.], v. 96, n. 1, p. 1-32, 2011. https://doi.org/10.1086/449521

KAHN, C. Pitágoras e os pitagóricos: uma breve história. São Paulo: Loyola, 2007. KERFERD, G. O movimento sofista. São Paulo: Loyola, 2003.

KRANZ, W. Die griechische Philosophie: Zugleich eine Einführung in die Philosophie überhaupt. Birsfelden-Basel: Schibli-Doppler, 1981.

LAÉRCIO, D. Vidas e doutrinas dos filósofos ilustres. Tradução de Mário G. Kury. Brasília: UnB, 1988.

LESKY, A. A history of Greek literature. New York: Apollo Editions, 1963.

LIDELL, H. G.; SCOTT, R. A Greek-English lexicon. Oxford: Clarendon, 1996.

MONDOLFO, R. O homem na cultura antiga. São Paulo: Mestre Jou, 1968.

MÜLLER, C. W. Protagoras über die Götter. In: CLASSEN, C. J. (hersg.). Sophistik. Darmstadt: Wissenschaftliche Buchgesselschaft, 1976. p. 312-341.

PLATÃO. Platonis Opera. New York: Oxford University, 1961. t. 1.

PLATÃO. Platonis Opera. New York: Oxford University, 1957. t. 2.

PLATÃO. Platonis Opera. New York: Oxford University, 1957. t. 3.

PLATÃO. Platonis Opera. New York: Oxford University, 1957. t. 4.

PLUTARCH. Lives, Pericles and Fabius Maximus, Nicias and Crassus. Cambridge: Harvard University, 1916.

REALE, G. História da Filosofia Grega. 5. ed. São Paulo: Loyola, 2005. v. 1. 
TATE, J. Greek for 'Atheism'. The Classical Review, [s. l.], v. 50, n. 1, p. 3-5, 1936.

TATE, J. More Greek for 'Atheism'. The Classical Review, [s. l.], v. 51, n. 1, p. 3-6, 1937.

TAURECK, B. H. F. Die Sophisten zur Einführung. Wiesbaden: Panorama Verlag, 1995.

TUCÍDIDES. História da guerra do Peloponeso. 3. ed. Tradução de Mário da Gama Kury. Brasília: UnB, 1987.

UNTERSTEINER, M. A obra dos sofistas: uma interpretação filosófica. São Paulo: Paulus, 2012.

VERSENYI, L. Protagoras' Man-Measure Fragment. In: CLASSEN, C. J. (hrsg.). Sophistik. Darmstadt: Wissenschaftliche Buchgesselschaft, 1976. p. 290-298. ZELLER, E. Grundriss der Geschichte der griechischen Philosophie. Vierte Auflag. Leipzig: O. R Reisland, 1893.

\section{Endereço Postal:}

M. R. Engler

Universidade Federal do Paraná (UFPR). Setor de Ciências Humanas - Filosofia Rua Dr. Faivre, 405- $6^{\circ}$ andar - Ed. D. Pedro II, CEP: 80060-140 - Curitiba - Paraná - Brasil. 